\title{
PENDEKATAN KRITIS MENANGKAL HOAX
}

\author{
Adi Ekopriyono \\ Dosen Fakultas Ekonomi Bisnis Universitas Tujuh Belas Agustus Semarang \\ Email: adi-eko-priyono@untagsmg.ac.id
}

\begin{abstract}
ABSTRAK
Pembangunan nasional direcoki oleh hoax, yaitu informasi palsu, berita bohong, dan fakta yang dipelintir demi kepentingan tertentu. Fenomena ini sebagai konsekuensi kemajuan pesat teknologi informasi. Liberalisasi informasi dan transparansi komunikasi nyaris tidak terbentung. Energi bangsa terkuras untuk hal-hal yang tidak begitu penting, sehingga laju pembangunan pun tersendat. Media sosial dengan bermacam-macam hoax-nya sudah sangat dominan dalam relasi dengan masyarakat. Tulisan ini merupakan pengembangan dari hasil penelitian yang dilakukan penulis, yaitu Penelitian "Keberpihakan Pers dalam Konflik Ambon (Analisis Framing terhadap Pemberitaan Suara Pembaruan, Republika, dan Kompas)." Penelitian tersebut dilakukan pada tahun 2002. Kesimpulan dari pengembangan penelitian tersebut adalah, bahwa pendekatan kritis merupakan jawaban. Melalui pendekatan kritis pemberdayaan masyarakat dilakukan untuk menghadapi hoax, sehingga tidak mudah "termakan" informasi palsu, berita bohong, dan fakta yang dipelintir. Pendekatan Kritis menjadi sangat relevan pada saat bangsa ini menyongsong pemilihan presiden (Pilpres) 2019, ketika hoax makin merajalela dengan sentuhan-sentuhan bernuansa suku, agama, ras, dan antargolongan (SARA). Pendekatan Kritis dapat diterapkan untuk mengeliminasi ancaman-ancaman terhadap keutuhan Negara Kesatuan Republik Indonesia (NKRI).
\end{abstract}

Kata kunci: Hoax, pemberdayaan, media sosial, pembangunan, kritis.

\section{PENDAhUluAN}

Pada era digitalisasi saat ini, semua orang dapat menjadi wartawan; melaksanakan kegiatan jurnalistik, yaitu mencari, memperoleh, memiliki, menyimpan, mengolah, dan menyampaikan informasi, baik dalam bentuk tulisan, suara, gambar, suara dan gambar serta data dan grafik maupun dalam bentuk lainnya dengan menggunakan media cetak, media elektronik, dan segala jenis saluran yang tersedia. Kegiatan tersebut dilakukan, terutama melalui media sosial (medsos).

Orang dapat "bicara" tentang apa saja lewat whatsapp, facebook, twitter, instagram, line, telegram, dan berbagai saluran yang lain. Hal ini menyebabkan konsekuensi terkait dengan prinsipprinsip pers. Prinsip check and re-check, cover both sides, konfrmasi, tidak lagi dipedulikan.

Akibat selanjutnya, muncul berbagai masalah, antara lain hoax. Secara umum, hoax adalah informasi palsu, berita bohong, atau fakta yang dipelintir atau direkayasa. Masalah inilah yang sekarang menambah persoalan dalam pembangunan nasional. Terlebih lagi, hoax yang dikaitkan dengan aspek SARA (suku agama, ras, dan antargolongan) serta hal-hal yang bernuansa politik.

Terjadi "pertarungan wacana" dalam kehidupan berbangsa dan bernegara. Banyak definisi tentang istilah wacana, ada yang mengartikan sebagai unit bahasa yang lebih besar dari kalimat, ada pula yang mengartikan sebagai pembicaraan atau diskursus. Kata ini dipakai oleh berbagai kalangan, mulai dari studi bahasa, psikologi, sosiologi, politik, komunikasi, sastra, dan sebagainya. Luasnya makna disebabkan oleh perbedaan lingkup dan disiplin ilmu yang menggunakan istilah tersebut. Pemakaian istilah ini sering diikuti dengan beragamnya istilah, definisi, bukan hanya tiap disiplin ilmu mempunyai istilah sendiri, melainkan juga banyak ahli memberikan definisi dan batasan yang berbeda. Bahkan, kamus pun mempunyai definisi yang berbeda-beda pula (Eriyanto, 2001, 2002).

Kemudian muncul istilah analisis wacana, yang juga telah digunakan dalam berbagai macam arti, yang mencakup berbagai macam kegiatan. Istilah tersebut digunakan untuk mendeskripsikan kegiatan-kegiatan pada persilangan berbagai disiplin linguistik yang berbeda, seperti sosiolinguistik, psikolinguistik, linguistik filosofis, dan linguistik komputasi (Brown, Gilian, \& Yule, 1996). 
Dalam kaitan dengan pemilihan presiden 2019 misalnya, kita dapat melihat betapa dahsyatnya "pertarungan wacana" tersebut antara pendukung Jokowi dan pendukung Prabowo. Perebutan simpati masyarakat melalui medsos makin tidak terkendali. Muncul istilah "cebong" untuk pendukung Jokowi dan istilah "kampret" untuk pendukung Prabowo, yang dalam prinsip-prinsip jurnalistik konvensional pasti dihindari.

Pemeo journalist also have a heart (Wartawan juga punya hati) tidak lagi dihiraukan. Caci-maki menghiasi Medsos nyaris tanpa kontrol. Hoax beterbaran di mana-mana, dan orang sulit menentukan mana informasi yang akurat-valid, mana informasi yang palsu.

Tulisan ini merupakan pengembangan dari hasil penelitian yang dilakukan penulis berjudul "Keberpihakan Pers dalam Konflik Ambon (Analisis Framing terhadap Pemberitaan Suara Pembaruan, Republika, dan Kompas)" (Ekopriyono, 2002). Penelitian tersebut merupakan penajaman dari hasil riset media dengan bahan baku riset media berupa kliping-kliping dari 11 surat kabar, yaitu Kompas, Suara Pembaruan, Republika, Merdeka, Media Indonesia, Suara Karya, Bisnis Indonesia, the Jakarta Post, Suara Merdeka, SoloPos, dan Jawa Pos (Ekopriyono \& Prabowo, 1999). Hasil penelitian tersebut kemudian diterapkan untuk menganalisis perkembangan kebebasan pers, terutama kemerebakan hoax di media sosial.

\section{PERKEMBANGAN PERS}

Selama pemerintahan Orde Baru, pers terbelenggu oleh kekuasaan yang represif. Pengertian pers dalam tulisan ini mengacu pada Undang-Undang Nomor 40 Tahun 1999 tentang Pers. Dalam pengertian UU ini (Tunggal, 2000) yang dimaksud dengan pers, tidak hanya media cetak, melainkan juga media elektronik dan segala bentuk saluran yang tersedia. Dalam pasal 1 (1) disebutkan: Pers adalah lembaga sosial dan wahana komunikasi massa yang melaksanakan kegiatan jurnalistik meliputi mencari, memperoleh, memiliki, menyimpan, mengolah, dan menyampaikan informasi, baik dalam bentuk tulisan, suara, gambar, suara dan gambar serta data dan grafik maupun dalam bentuk lainnya dengan menggunakan media cetak, media elektronik, dan segala jenis saluran yang tersedia.

Konsepsi tentang pers bebas bertanggung jawab tidak pernah terwujud. Demikian pula konsepsi tentang Pers Pancasila, hanya dijadikan kedok oleh penguasa Orde Baru untuk melakukan pembatasan-pembatasan.

Ketika itu setiap penerbitan diwajibkan memiliki Surat Izin Usaha Penerbitan Pers (SIUPP). Pemerintah sewaktu-waktu dapat mencabut SIUPP kalau suatu penerbitan memuat tulisan yang dinilai tidak sesuai dengan kebijakan pemerintah. Alasan yang sering digunakan antara lain mengganggu stabilitas dan atau tidak sejalan dengan semangat pembangunan.

Beberapa penerbitan telah mengalami pencabutan SIUPP selama masa kekuasaan Soeharto tersebut. Pemberitaan pers tentang Peristiwa 15 Januari 1974 (Malari) menyebabkan beberapa suratkabar terkemuka ditutup untuk selamanya, antara lain: Nusantara, Pedoman, Indonesia Raya, Abadi, Jakarta Times, dan Mahasiswa Indonesia. Pemberedelan juga terjadi pada tahun 1994. SIUPP tiga majalah, yaitu Tempo, Editor, dan Detik dibatalkan, karena memberitakan kasus pembelian kapal bekas dari eks negara Jerman Timur.

Pencabutan SIUPP pada saat itu menjadi "momok" bagi setiap penerbitan, karena tidak hanya mengancam penerbitannya sendiri melainkan juga seluruh karyawan yang bernaung di dalamnya. Pencabutan SIUPP berarti penghentian kegiatan semua unit usaha penerbitan, tidak hanya unit redaksi yang mengelola secara langsung suatu pemberitaan.

Keterbelengguan kebebasan pers sebenarnya tidak hanya terjadi pada era pemerintahan Soeharto. Sebelum itu, pers Indonesia pun telah digunakan sebagai alat perjuangan politik oleh partai-partai politik, sehingga sedikit sekali suratkabar yang berhasil memelihara kebebasannya sendiri. Dalam keadaan demikian, menurut Mochtar Lubis dalam Kebebasan Pers dan Arus Informasi di Indonesia (Jakarta, 1981), Presiden Soekarno akhirnya menjadikan pers Indonesia sebagai "alat revolusi". Hasilnya adalah kerusakan mendalam terhadap nilai-nilai jurnalistik dan kebebasan pers di Indonesia. 
Kebebasan pers mulai terasa pada masa pemerintahan transisi Baharuddin Jusuf Habibie. Kepemimpinan Habibie, dengan Menteri Penerangan Letjen TNI Yunus Yosfiah, menerapkan kebijakan pers yang lebih liberal. Pemerintah memberi kemudahan memperoleh SIUPP. Pada masa pemerintahan Habibie yang singkat, Mei - Oktober 1998, sudah dikeluarkan lebih dari 1.600 SIUPP baru. Bandingkan dengan pemerintahan Soeharto, yang selama 32 tahun hanya mengeluarkan sekitar 300 SIUPP (Hidayat, 1999).

Pers menemukan kebebasan yang substansial setelah Indonesia berada di bawah kepemimpinan KH Abdurrahman Wahid. Langkah Presiden Wahid menghapus Departemen Penerangan (Deppen) ibarat puncak dalam proses keterbukaan dan demokratisasi kehidupan pers di Indonesia. Bersama penghapusan Deppen, maka hilang pula lembaga SIUPP yang selama masa Orde Baru menjadi penghalang terwujudnya kebebasan pers.

Pers memasuki era baru di bawah kepemimpinan Abdurrahman Wahid tersebut. Dengan hilangnya lembaga SIUPP, maka pers dapat memberitakan secara bebas semua peristiwa, tanpa dibayangi pemberangusan (pemberedelan). Dinamika kehidupan pers pun meningkat, sehingga pemberitaan yang disajikan menjadi lebih bervariasi. Pemerintah tidak lagi mencampuri urusan penerbitan, namun justru mengembalikannya kepada dunia penerbitan sendiri, yang berarti pula mengembalikan kepada masyarakat.

Pers Indonesia menemukan kebebasan yang belum pernah mereka rasakan selama berpuluhpuluh tahun, sejak pemerintahan kolonial Hindia Belanda, pemerintahan Presiden Soekarno, sampai era Orde Baru di bawah kepemimpinan Soeharto. Keterbelengguan yang sangat lama itu, menimbulkan euforia kebebasan ketika pers memperolehnya.

Kebebasan yang terbuka lebar-lebar, dapat mengakibatkan pers lupa diri. Sebagian pers menggunakan kebebasan itu secara berlebihan, sehingga menimbulkan berbagai dampak. Kasus penyerbuan para pemuda Barisan Serba Guna (Banser) Gerakan Pemuda Ansor terhadap kantor redaksi harian Jawa Pos di Surabaya pada saat itu merupakan salah satu contoh dari beberapa kasus ketidakpuasan masyarakat terhadap pemberitaan pers. "Penyerbuan" tersebut terjadi setelah suratkabar harian itu dinilai oleh Barisan Serba Guna (Banser) memuat berita-berita yang menyudutkan Presiden KH. Abdurrahman Wahid.

Ketika itu, pers tidak lagi berhadapan dengan aparat negara seperti terjadi pada masa Soeharto, melainkan berhadapan dengan masyarakat. Pers sering dibayang-bayangi kekhawatiran diprotes atau bahkan diserbu massa yang tidak puas terhadap pemberitaan. Hak jawab yang diatur dalam UU Nomor 40 Tahun 1999 sebagai hak yang dimiliki pihak yang dirugikan oleh suatu pemberitaan, sering tidak disukai. Menurut UU 40/1999 tentang Pers, hak jawab adalah hak seseorang atau sekelompok orang untuk memberikan tanggapan atau sanggahan terhadap pemberitaan berupa fakta yang merugikan nama baiknya.Menurut pengalaman dan pengamatan penulis, ada kecenderungan masyarakat, atau setidak-tidaknya sebagian masyarakat, lebih senang memilih jalur hukum (dengan mensomasi pers) atau melancarkan protes dalam berbagai cara, misalnya unjuk rasa atau mendatangi kantor redaksi.

Pers dan masyarakat mengalami euforia yang sama, yaitu euforia kebebasan. Pers merasa bertanggung jawab menjalankan kebebasannya dalam menyebarkan informasi, masyarakat merasa memiliki kebebasan untuk bertindak sesuai kehendak mereka kalau merasa dirugikan oleh suatu pemberitaan. Terdapat benturan antara keduanya dan kalau tidak ada jalan keluar, maka kebebasan pers justru dapat menjadi bumerang bagi kehidupan pers sendiri. Dapat terjadi adu kekuatan di antara keduanya; kalau pers yang lebih kuat maka yang terjadi adalah pers menekan masyarakat, sebaliknya kalau masyarakat yang lebih kuat maka masyarakat yang menekan pers.

Sudah terdapat rambu-rambu untuk mengatasi hal tersebut, berupa aturan-aturan operasional kegiatan jurnalistik yang tertuang dalam UU Nomor 40 Tahun 1999. Di antara aturan tersebut adalah, bahwa wartawan harus melakukan check and re-check sebelum memuat berita, wartawan harus memberitakan suatu peristiwa secara berimbang, tidak sepihak. Dalam praktik, meskipun prinsip- 
prinsip itu sudah dilakukan, namun tidak jarang pihak yang diberitakan tetap merasa dirugikan dan tidak bersedia menggunakan hak jawab serta jalur hukum.

Di lain pihak, tidak jarang dijumpai wartawan memuat berita tanpa melakukan check and recheck. Alasan yang biasa mereka gunakan adalah keterbatasan waktu karena dikejar deadline atau pihak yang akan dikonfirmasi tidak atau belum dapat ditemui.

Pers adalah juga realitas dalam dirinya sendiri. Pers mempunyai fungsi ideologis dan melakukan manuver politik sesuai dengan fungsi ideologinya. Hal ini akan mencakup masalah siapa, kepentingan apa, dan perspektif mana yang akan memperoleh akses ke media mereka. Di luar fungsi ideologis yang dijalankan, bagaimanapun, media pertama-tama perlu dilihat sebagai institusi ekonomi. Oleh karena itu, manuver politik yang dijalankan melalui politik pemberitaannya juga dikemas sebagai komoditi informasi yang berusaha menyiasati tuntutan serta peluang pasar. Pemain industri media kita tampaknya hanya akan terdiri atas kaum yang itu-itu saja. Media pun memiliki fungsi ideologinya (Sudibyo, 2001).

Dalam teori jurnalistik disebutkan, bahwa pers mempunyai fungsi sebagai berikut: memberi pendidikan (education), memberi informasi (information), dan memberi hiburan (entertainment). Tiga fungsi itu dilakukan dalam bingkai membentuk pendapat umum (public opinion). Oleh karena itu, peranan pers sangat besar dalam konteks pemberdayaan masyarakat. Pers dapat memberikan pendidikan kepada masyarakat mengenai kebijakan-kebijakan pemerintah, memberikan informasi tentang kegiatan dan dinamika masyarakat, memberikan hiburan kepada masyarakat di tengahtengah berbagai krisis. Dalam melakukan fungsi-fungsi tersebut, pers membentuk pendapat umum, sehingga sangat berpengaruh terhadap kehidupan masyarakat dan negara.

Besarnya tingkat pengaruh pers terhadap kehidupan masyarakat dan negara tersebut dikemukakan oleh Dedy N. (Hidayat, 1999) ketika menjelaskan mengenai ruang publik (public sphere). Diskursus seputar media massa, khususnya dalam konteks kajian demokratisasi, pada akhirnya akan sulit mengesampingkan keberadaan konsep public sphere, yang pertama kali dikembangkan oleh salah seorang tokoh pencerahan, yakni Habermas.

Ruang publik merujuk pada suatu celah di antara negara dan masyarakat, ketika setiap individu warga negara dapat melibatkan diri dalam diskursus tentang berbagai isu bersama, dalam kerangka pencapaian konsensus di antara mereka sendiri atau untuk mengontrol negara dan pasar. Dalam proses tersebut pers menempati posisi sentral, khususnya dalam era peradaban ketika praktis semua manusia menjadi bagian dari kesepakatan untuk bersatu dalam kesatuan-kesatuan politik besar, seperti negara.

Dalam konteks itu, pers menyuplai dan menyebarluaskan informasi yang diperlukan untuk penentuan sikap dan memfasilitasi pembentukan pendapat umum. Dalam menjalankan fungsi tersebut, pers menempatkan diri sebagai wadah yang independen pada saat isu umum dapat diperdebatkan. Meskipun berusaha menempatkan diri sebagai wadah independen, pemberitaan pers selalu dipengaruhi oleh latar belakang pers sebagai suatu realitas tersendiri. Ideologi pers selalu memengaruhi politik pemberitaannya, oleh karena itu masyarakat sebagai konsumen harus diberi pemahaman sehingga dapat menelaah secara tepat berbagai informasi yang disampaikan pers.

Asumsi yang berkembang adalah reformasi telah mengubah performa dan sikap pers secara umum. Pers pada era reformasi diasumsikan tidak lagi terkungkung dalam keseragaman isi dan kemasan, melainkan bebas mengembangkan model pemberitaan sesuai dengan kehendaknya.

Di sisi lain, sulit untuk dipercayai bahwa pers merupakan entitas yang benar-benar otonom dan mandiri. Walaupun pemerintahan sudah berganti dan iklim politik sudah memberikan keterbukaan mengemukakan pendapat, namun tetap diperlukan sikap kritis terhadap faktor-faktor eksternal yang mempunyai potensi untuk memengaruhi perilaku pers dalam mengonstruksi dan memaknai realitas.

Dalam konteks pembangunan masyarakat, pengembangan sikap kritis terhadap pemberitaan tersebut sangat penting, agar masyarakat memahami bahwa pemberitaan pers merupakan realitas media itu sendiri. Realitas media itu tidak selalu sama dengan realitas sesungguhnya, yakni peristiwa 
yang diberitakan. Pemahaman itu sangat berarti dalam rangka membebaskan masyarakat dari dominasi pers dalam membentuk opini publik.

\section{PARADIGMA KRITIS DAN PARADIGMA POSITIVISTIK}

Secara garis besar penelitian komunikasi dalat dikelompokkan menjadi dua, yaitu: Paradigma Positivistik dan Paradigma Kritis.

Menurut Geertz, masa keemasan positivisme sebagai suatu dogma metodologis telah usai dalam ilmu sosial. Meskipun demikian, di Indonesia, perspektif yang positivistik terlalu mendominasi metodologi penelitian komunikasi.

Konsep ilmu bebas nilai sebagaimana dianut para positivis makin ditinggalkan orang. Ilmuwan mulai mengimplikasikan nilai; mulai dari observasi, analisis, sampai kesimpulan. Ilmuwan mutakhir dengan pendekatan teori kritis mulai mengeksplisitkan ideologi dalam pengembangan ilmu. Eksplorasi ketidakadilan dalam banyak hal, mendorong sejumlah ilmuwan kritis memasalahkan praktik-praktik kehidupan yang tidak adil (Muhadjir, 2000).

Banyak peneliti positivis di Indonesia yang menolak metode penelitian komunikasi yang humanistik (fenomenologis, interaksionis, dan kritis). Penolakan itu kurang masuk akal, karena sebenarnya keistimewaan ilmu sosial, termasuk ilmu komunikasi, terletak pada keanekaragaman perspektifnya. Keanekaragaman tersebut disebabkan oleh rumitnya fenomena komunikasi.

Dominasi metodologis itu merupakan kendala terbesar dalam penelitian komunikasi di Indonesia. Para peneliti positivis cenderung etnosentrik, menganggap bahwa metode mereka merupakan satu-satunya yang sah dalam mengkaji fenomena komunikasi. Ketika seorang kandidat sarjana S1, S2, atau S3 mempertahankan skripsi, tesis, atau disertasi dengan menggunakan pendekatan kualitatif, tidak jarang para penguji positivis menilai karya penelitian tersebut dengan standar ilmiah yang positivistik.

Paradigma kritis melihat bahwa media bukan saluran yang bebas dan netral. Media justru dimiliki oleh kelompok tertentu dan digunakan untuk mendominasi kelompok yang lain. Aliran kritis memandang struktur sosial sebagai konteks yang sangat menentukan realitas, proses, dan dinamika komunikasi, termasuk komunikasi massa. Penelitian komunikasi yang mengabaikan struktur sosial dipandang sebagai ahistoris.

Paradigma kritis berargumentasi, melihat komunikasi dan proses yang terjadi di dalamnya harus dengan pandangan yang holistik. Menghindari konteks sosial akan menghasilkan distorsi yang serius.

Terdapat perbedaan yang mendasar antara paradigma positivistik dan paradigma kritis. Paradigma positivistik menggunakan analisis kuantitatif dengan kategorisasi yang ketat dan analisis statistik, melalui pengujian hipotesis tertentu. Paradigma kritis pada umumnya bersifat kualitatif dan menggunakan penafsiran sebagai basis utama memaknai temuan.

Dalam studi teks berita, paradigma kritis berpandangan bahwa berita bukan sesuatu yang netral. Media merupakan ruang tempat kelompok dominan menyebarkan pengaruhnya dengan berusaha meminggirkan kelompok lain yang tidak dominan. 
Perbandingan karakteristik penelitian teks berita menurut paradigma kritis dan paradigma positivistik dapat digambarkan sebagai berikut:

\begin{tabular}{|l|l|}
\hline \multicolumn{1}{|c|}{ PANDANGAN POSITIVISTIK } & \multicolumn{1}{|c|}{ PANDANGAN KRITIS } \\
\hline \multicolumn{2}{|c|}{ Fakta } \\
\hline $\begin{array}{l}\text { Ada fakta yang real, yang diatur oleh kaidah-kaidah tertentu } \\
\text { yang berlaku universal. }\end{array}$ & $\begin{array}{l}\text { Fakta merupakan hasil dari proses pertarungan antara } \\
\text { kekuatan ekonomi, politik, dan sosial yang ada dalam } \\
\text { masyarakat. }\end{array}$ \\
\hline $\begin{array}{l}\text { Berita adalah cermin dan refleksi dari kenyataan. Oleh } \\
\text { karena itu, berita haruslah sama dan sebangun dengan fakta } \\
\text { yang hendak diliput. }\end{array}$ & $\begin{array}{l}\text { Berita tidak mungkin merupakan cermin dan refleksi dari } \\
\text { realitas, karena berita yang terbentuk hanya cerminan dari } \\
\text { kepentingan kekuatan dominan. }\end{array}$ \\
\hline
\end{tabular}

Posisi Media

Media adalah sarana yang bebas dan netral, tempat semua kelompok masyarakat saling berdiskusi yang tidak dominan. Media menggambarkan diskusi apa yang ada dalam masyarakat.

Media hanya dikuasai oleh kelompok dominan dan menjadi sarana untuk memojokkan kelompok lain. Media hanya dimanfaatkan dan menjadi alat kelompok dominan.

Posisi Wartawan

\begin{tabular}{|l|l|}
\hline $\begin{array}{l}\text { Nilai dan ideologi wartawan berada di luar proses peliputan } \\
\text { berita. }\end{array}$ & $\begin{array}{l}\text { Nilai dan ideologi wartawan tidak dapat dipisahkan dari } \\
\text { proses peliputan dan pelaporan suatu peristiwa. }\end{array}$ \\
\hline Wartawan berperan sebagai pelapor. & $\begin{array}{l}\text { Wartawan berperan sebagai partisipan dari kelompok } \\
\text { yang ada dalam masyarakat. }\end{array}$ \\
\hline $\begin{array}{l}\text { Tujuan peliputan dan penulisan berita: eksplanasi dan } \\
\text { menjelaskan apa adanya. }\end{array}$ & $\begin{array}{l}\text { Tujuan peliputan dan penulisan berita: pemihakan } \\
\text { kelompok sendiri dan atau pihak lain. }\end{array}$ \\
\hline Penjaga gawang (gatekeeping). & Sensor diri. \\
\hline Landasan etis. & Landasan ideologis. \\
\hline Profesionalisme sebagai keuntungan. & Profesionalisme sebagai kontrol. \\
\hline $\begin{array}{l}\text { Wartawan sebagai bagian dari tim untuk mencari } \\
\text { kebenaran. }\end{array}$ & $\begin{array}{l}\text { Wartawan sebagai pekerja yang mempunyai posisi } \\
\text { berbeda dalam kelas sosial }\end{array}$ \\
\hline
\end{tabular}

Hasil Liputan

\begin{tabular}{|l|l|}
\hline Liputan dua sisi, dua pihak, dan kredibel. & $\begin{array}{l}\text { Mencerminkan ideologi wartawan dan kepentingan sosial, } \\
\text { ekonomi, atau politik tertentu. }\end{array}$ \\
\hline $\begin{array}{l}\text { Objektif, menyingkirkan opini dan pandangan subjektif dari } \\
\text { pemberitaan. }\end{array}$ & $\begin{array}{l}\text { Tidak objektif, karena wartawan adalah bagian dari } \\
\text { kelompok/struktur sosial tertentu yang lebih besar. }\end{array}$ \\
\hline $\begin{array}{l}\text { Memakai bahasa yang tidak menimbulkan penafsiran yang } \\
\text { beraneka. }\end{array}$ & $\begin{array}{l}\text { Bahasa menunjukkan bagaimana kelompok sendiri } \\
\text { diunggulkan dan memarjinalkan kelompok lain. }\end{array}$ \\
\hline
\end{tabular}

Sumber: (Eriyanto, 2001)

Dalam suasana penuh hoax diperlukan kekritisan masyarakat, agar bangsa ini tidak terjerumus pada kondisi yang lebih parah, seperti beberapa bangsa lain yang telah menjadi korban. Masyarakat perlu diberdayakan agar tidak "termakan" oleh dominasi hoax.

Kini, Medsos menempati posisi yang dominan dalam relasinya dengan masyarakat. Ada ketimpangan dalam relasi tersebut, sehingga masyarakat menempati posisi yang dirugikan karena jarang memperoleh informasi dengan tingkat objektivitas yang tinggi. Objektivitas berita merupakan suatu dimensi, sehingga ada degradasi atau tingkatannya. Objektivitas bukanlah suatu nilai, yang dapat diukur secara mutlak; berita ini objektif, berita itu tidak objektif.

Tingkat objektivitas berita tergantung dari tingkat kedalaman pemaknaan di balik fakta dalam proses penulisan. Makin dalam investigasi untuk mengungkap informasi di balik fakta, atau dalam dunia jurnalistik dikenal sebagai berita di balik berita (news behind the news), maka akan makin tinggi objektivitasnya. Sebaliknya, makin dangkal investigasi untuk menemukan berita di balik berita akan makin rendah tingkat objektivitasnya. 
Kemarakan hoax akhir-akhir ini makin diperparah dengan kecenderungan orang lebih menyukai informasi-informasi negatif. Hal itu, menambah pembenaran bahwa berita yang buruk adalah berita yang baik, seperti ditengarai oleh Edwin Diamond (Diamond, 1980).

Media sosial dengan hoax yang marak juga mengaburkan teori (McQuail, 1992) yang menyebutkan factor-faktor yang berpengaruh terhadap pers, antara lain pemilik perusahaan, kelompok penekan, pemasang iklan, lembaga sosial-politik, dan pemerintah. Media sosial relatif terbebas dari faktor-faktor tersebut.

\section{KESIMPULAN}

Media sosial sangat rentan dengan aspek objektivitas. Orang menulis di Medsos tidak menghiraukan apakah tulisannya itu objektif atau tidak. Bahkan, orang tidak menghiraukan apakah tulisannya itu didasari investigasi atau tidak, merugikan orang lain atau tidak. Kadang orang justru sekadar mengirim tulisan orang lain ke grup-grup Medsos tanpa mempertimbangkan akibatnya. Hoax makin neyebar.

Oleh karena itu, pendekatan kritis merupakan jawaban atas kemerabakan hoax. Pendekatan kritis, yang selalu mempertanyakan kebenaran fakta dan berusaha mengungkapkan makna di balik fakta, akan membawa pada penyajian informasi yang lebih investigatif. Dengan demikian, informasi yang disajikan bukan sekadar realitas semu yang nampak di atas permukaan, melainkan lebih mendekati realitas yang sesungguhnya.

Pendekatan kritis akan membimbing masyarakat untuk lebih bersikap kritis terhadap informasi yang mereka peroleh. Dengan demikian, masyarakt tidak mudah terpengaruh oleh informasi yang sering simpang-siur pada masa reformasi sekarang ini, terlebih lagi mendekati pemilihan presiden 2019.

Pendekatan kritis diharapkan dapat mengurangi kekentalan frame Medsos yang selalu ingin memenangkan kelompok atau ideologi tertentu dan meminggirkan kelompok atau ideologi yang lain. Pendekatan kritis akan memberikan pemahaman kepada masyarakat mengenai adanya perbedaan antara realitas Medsos dan realitas sosial. Dengan demikian, masyarakat tidak mudah terhasut oleh berita-berita bohong dan informasi palsu.

Mengapa pemberdayaan masyarakat penting? Karena, pada era reformasi sekarang ini Medsos lebih dominan dibandingkan dengan media konvensional pada era sebelumnya.

Selama ini pemberdayaan memang sudah dilakukan, misalnya melalui pembentukan lembaga media watch, ombudsman, dan lembaga-lembaga swadaya masyarakat (LSM), namun langkahlangkah itu masih perlu ditingkatkan lagi.

Pada akhirnya, demokratisasi informasi memang terletak pada dinamika relasi Medsos dan masyarakat tersebut. Meskipun hoax berseliweran di berbagai Medsos, namun kalau masyarakat kritis dan memahami bahwa Medsos mempunyai realitasnya sendiri, maka masyarakat akan menyikapi informasi yang disajikan sebagai bagian dari informasi secara keseluruhan, bukan satusatunya informasi yang paling benar.

Pemberdayaan masyarakat akan mengurangi ketimpangan relasi Medsos dan masyarakat, sehingga masing-masing pihak akan berada pada posisi yang tepat. Media sosial berusaha menyajikan informasi yang menurut mereka mempunyai nilai jual, sementara itu masyarakat mengonsumsi informasi tersebut hanya sebagai bagian realitas, yang masih harus dipertanyakan kebenarannya. 


\section{DAFTAR PUSTAKA}

Brown, Gilian, \& Yule, G. (1996). Analisis Wacana. Jakarta: Gramedia Pustaka Utama.

Diamond, E. (1980). Good News, Bad News. Massachusetts: The Massachusetts Institute of Technology.

Ekopriyono, A. (2002). Keberpihakan Pers dalam Konflik Ambon (Analisis Framing terhadap Pemberitaan Suara Pembaruan, Republika, dan Kompas). Satya Wacana University.

Ekopriyono, A., \& Prabowo, A. (1999). Ketika Amarah Membuncah (Kajian Media dan Literatur terhadap Berbagai Peristiwa Kerusuhan Sosial di Indonesia). Semarang: Limpad.

Eriyanto. (2001). Analisis Wacana: Pengantar Analisis Teks Media. Yogyakarta: LkiS.

Eriyanto. (2002). Analisis Framing: Konstruksi, Ideologi, dan Politik Media. Yogyakarta: LkiS.

Hidayat, D. N. (1999). Menuju Paradigma Baru Penelitian. Ikatan Sarjana Komunikasi, 1 (Komunikasi).

McQuail, D. (1992). Media Performance, Mass Communication and the Public Interest. London: SAGE Publications.

Muhadjir, N. (2000). Metodologi Penelitian Kualitatif. Yogyakarta: Rake Sarasin.

Sudibyo, A. (2001). Politik Media dan Pertarungan Wacana. Yogyakarta: LkiS.

Tunggal, H. S. (2000). Undang-Undang Nomor 40 Tahun 1999 tentang Pers. Jakarta: Harvarindo. 